\title{
ТЕОРЕТИЧНІ ЗАСАДИ ЛІНГВОКОНЦЕПТОЛОГІЇ ЯК НАУКИ ПРО КОНЦЕПТИ
}

\section{Плотнікова Н. В.}

\section{ВСТУП}

Вимоги інтеграції лінгвістичного, когнітивного та психологічного в сучасних лінгвістичних студіях висувають на перший план вивчення людини: їі свідомості, мислення, матеріалізованих у мові. Особливого значення набуває культура, яка розглядається як найбільш фундаментальний спосіб людського буття. Останніми роками зросло зацікавлення до явища взаємодії двох феноменів людської життєдіяльності - мови і культури. Саме тому проблема дослідження культурної самобутності народу, що відображається у мовній картині світу, набуває все більшої значущості. Мовна картина світу тісно пов'язана із концептуальною картиною світу, оскільки остання існує у вигляді концептів, що мають мовне вираження та становлять предмет лінгвістичної концептології.

Лінгвістична концептологія як наукова галузь сформувалась порівняно недавно - на початку XXI сторіччя. Визначальним завданням для неї $є$ експлікація концептів, що складають концептуальну картину світу, в якій зберігається знання. Значний внесок у становлення лінгвоконцептології зробили представники різних сучасних вітчизняних лінгвістичних шкіл, зокрема І. Голубовська, С. Жаботинська, В. Жайворонок, А. Загнітко, В. Іващенко, Т. Космеда, А. Приходько, Т. Радзієвська, О. Селіванова, Ж. Соколовська. Чільне місце в цій галузі належить таким лінгвоконцептологам радянського та пострадянського простору, як М. Алефіренко, Н. Арутюнова, О. Бабушкін, М. Болдирев, С. Воркачов, В. Воробйов, В. Карасик, О. Кубрякова, Д. Лихачов, С. Ляпін, В. Маслова, В. Нерознак, С. Нікітіна, М. Піменова, 3. Попова, О. Рахіліна, Г. Слишкін, Й. Стернін, Ю. Степанов, В. Телія, Р. Фрумкіна. Серед представників західних шкіл варто згадати прізвища Є. Бартмінського, А. Вежбицької, Ф. Джонсон-Лерда, Д. Лакоффа, Р. Павільоніса, Ч. Філлмора, У. Чейфа. Праці зазначених мовознавців становлять підгрунтя для подальших розвідок у галузі лінгвоконцептології і є базою цього дослідження. 


\section{1. Становлення лінгвістичної концептології як наукової галузі}

Мовознавці розглядають історію лінгвістики як послідовну зміну наукових парадигм: 1) генетичної або порівняльно-історичної (перша у лінгвістиці XIX ст.), спрямованої на дослідження генетичної спорідненості мов світу; 2) таксономічної або системно-структурної (перша половина XX ст.), об'єкт дослідження якої становили предмет, номінація, ім'я, тому в центрі уваги було слово; 3) антропоцентричної (друга половина XX ст.), що грунтується на пізнанні людиною світу через самоусвідомлення. Зрушення парадигми лінгвістичних досліджень у бік антропоцентричного бачення та розуміння мовних явищ $\epsilon$ визначальною рисою сучасного мовознавства. Сучасний антропоцентричний підхід до мови, що сягає ідей В. фон Гумбольдта, «передбачає більш масштабне осмислення функцій мови, вихід за межі вузькораціонального, прагматичного трактування ï призначення» ${ }^{1}$.

Сьогодні мовознавство вивчає зв'язок мови 3 мисленням людини, загальнолюдськими та національно-культурними цінностями, тобто антропоцентрична парадигма - це переключення інтересів дослідника 3 об'єктів на суб'єкта пізнання. Як зазначає І. Голубовська, «визначилася настанова досліджувати мову в нерозривному зв'язку з мисленням, свідомістю, пізнанням, культурою, світоглядом як окремого індивідуума, так і мовного колективу, до якого він належить»². Основні галузі знань, що грунтуються на спільних теоретико-методологічних засадах і принципах та формуються у межах цієї парадигми, - це теорія мовної комунікації, психолінгвістика, лінгвістична філософія, теорія мовленнєвих актів, лінгвістика тексту, лінгвопрагматика, етнолінгвістика, соціолінгвістика, когнітивна лінгвістика, лінгвокультурологія.

Тенденція до взаємопроникнення різних галузей наукового знання це одна із головних характеристик науки кінця XX ст. У сфері гуманітарних дисциплін відображенням цього прагнення до синтезу стало формування в 90-ті роки XX ст. нових парадигм, особливу цікавість серед яких (3 огляду на предмет цього дослідження) викликають лінгвокогнітологічна та лінгвокультурологічна парадигми. Погоджуючись із думкою В. Карасика та Г. Слишкіна про те, що «будьяке лінгвокультурологічне дослідження є одночасно і когнітивним» ${ }^{3}$, уважаємо доцільним розглянути теоретичний інструментарій як лінгвокультурології, так і когнітивної лінгвістики.

${ }^{1}$ Голубовська I.О. Етнічні особливості мовних картин світу : монографія. Київ, 2004. C. 5.

Там само. С. 5.

${ }^{3}$ Карасик В.И., Слышкин Г.Г. Базовые характеристики лингвокультурных концептов. Антология концептов: В 5 т.Москва : Генеза, 2007. Т. 1. 2007. С. 12. 
За свідченням 3. Попової та Й. Стерніна, «когнітивна лінгвістика це лінгвістичний напрям, що активно розвивається, визначаючи обличчя сучасної світової лінгвістичної науки» ${ }^{4}$. Когнітивна лінгвістика «розглядає мову як засіб отримання, зберігання, обробки, переробки й використання знань, спрямований на дослідження способів концептуалізації й категоризації певною мовою інтеріоризованої дійсності та внутрішнього рефлексивного досвіду» ${ }^{5}$. Головна відмінність лінгвокогнітології від інших когнітивних наук полягає в іiі матеріалі - «вона досліджує свідомість на матеріалі мови (інші когнітивні науки досліджують свідомість на власному матеріалі), а також в іiі методах - вона досліджує концепти та когнітивні процеси, робить висновки про типи та зміст концептів у свідомості людини на основі застосування до мови власне лінгвістичних методів аналізу 3 подальшою когнітивною інтерпретацією результатів дослідження» ${ }^{6}$.

Предмет вивчення когнітивної лінгвістики становить: 1) когнітивна семантика; 2) теорія образних схем (когнітивна метафора, метонімія); 3) дослідження дискурсу з когнітивних позицій; 4) різні форми подання знань (фрейми, скрипти, сценарії тощо); 5) концепти та моделювання світу 3 їх допомогою ${ }^{7}$. Необмеженість предмета вивчення лінгвокогнітології сприяла виникненню маргінальних із іншими мовознавчими дисциплінами галузей, зокрема поєднання семасіологічних та когнітивних досліджень відображено у фреймовій семантииі (Ч. Філлмор), що стала продовженням граматики відмінка; $y$ процедурній семантииі (Е. Чарняк, У. Чейф, Дж. Андерсон, У. Кук, Т. Виноград, Дж. Коупланд, Ф. Джонсон-Лерд, Ю. Городецький), що розглядає проблему паралельного сканування всієї фреймової інформації в процесі сприйняття мовлення та моделювання динамічних аспектів сприйняття мови, іiі породження у мисленні у межах систем штучного інтелекту; у прототиповій семантииі (Е. Рош, У. Лабов, А. Вежбицька, Дж. Лакофф, Д. Болінжер, Б. Берлін, П. Кей), що досліджує прототипи як екземпляри класу, які найбільше відображають його типові ознаки; у конщептуальній семантиці, що вивчає ментальну організацію концептів розуму людини (ментальний лексикон) (Р. Джекендофф, Дж. Атчисон, Р. Лангакр, Р. Павільоніс, С. Нікітіна). C. 3

${ }^{4}$ Попова З.Д., Стернин И. А. Когнитивная лингвистика. Москва : АСТ. 2007.

${ }^{5}$ Селіванова О.О. Сучасна лінгвістика: термінологічна енциклопедія. Полтава : Довкілля-К, 2006. С. 213.

${ }^{6}$ Попова 3.Д., Стернин И.А. Основные черты семантико-когнитивного подхода к языку Антология концептов: В 5 т.Москва : Генеза, 2007. Т. 1. 2007. С. 7.

7 Маслова В.А. Введение в когнитивную лингвистику: учебное пособие. Москва : Флинта : Наука, 2004. С. 26-27. 
Перспективними $є$ також маргінальні галузі когнітивної граматики, зокрема когнітивного синтаксису та теорії дискурсу (Т. ван Дейк, В. Кінч, М. Бірвіш, Д. Шпербер, Д. Уілсон, Х. Грайс, У. Леннерт $)^{8}$. Сьогодні посилено інтерес до проблем когнітивної лінгвістики й у пострадянському науковому просторі (О. Бабушкін, М. Болдирев, С. Жаботинська, В. Іващенко, О. Кубрякова, М. Піменова, 3. Попова, О. Рахіліна, О. Селіванова, Й. Стернін).

Як зазначають В. Дем'янков та О. Кубрякова, головними в когнітивній лінгвістиці стали «проблеми категоризація та концептуалізації, що розглядаються в численних публікаціях; проблеми мовної картини світу; проблеми співвіднесення мовних структур із когнітивними; проблеми частин мови тощо...» ${ }^{9}$. Попри те, що коло завдань сучасної лінгвокогнітології дуже широке, основне іiї завдання полягає «в описі та поясненні мовної здатності і / або знань мови як внутрішньої когнітивної структури і динаміки мовця-слухача» ${ }^{10}$.

Починаючи з XVIII ст., питання взаємозв'язку мови і культури постійно привертало увагу науковців у межах порівняльно-історичного мовознавства, психологічного напряму лінгвістики, неогумбольдтіанства, австрійської школи слів і речей, лінгвокраїнознавства, етнопсихолінгвістики (О. Ахманова, М. Бахтін, А. Вежбицька, В. Гумбольдт, О. Потебня, Е. Сепір, І. Срезневський, Б. Уорф, К. Хейл, Л. Щерба). У сучасній лінгвістиці мову розглядають як складник культури, головний засіб іiі засвоєння; культуру й мову іноді ототожнюють або включають першу до другої. Мова одночасно є й знаряддям творення, розвитку, зберігання (у вигляді текстів) культури та ii частиною, оскільки за допомогою мови створюються реальні витвори матеріальної та духовної культури. 3 урахуванням взаємозв'язку мови і культури в сучасному мовознавстві утворилась нова наукова галузь - лінгвокультурологія, що «стосується як культури, так і мови, але навряд чи було би правомірно розглядати категоріальний фонд цієї галузі знання як суму категорій двох наук, поєднаних проблемою взаємозв'язку мови та культури» ${ }^{11}$.

${ }^{8}$ Селіванова О.О. Актуальні напрями сучасної лінгвістики (аналітичний огляд). Київ : Видавництво Українського фітосоціологічного центру, 1999. С. 68-69.

Кубрякова Е.С. Краткий словарь когнитивных терминов [Текст] / Е.С. Кубрякова, В.З. Демьянков, Ю.Г. Панкрац, Л.Г. Лузина; / [под общ. ред. Е. С. Кубряковой]. Москва : Филологический факультет МГУ им. М.В. Ломоносова, 1996. C. 54.

10 Загнітко А.П. Сучасні лінгвістичні теорії : Монографія. Донецьк : ДонНУ, 2006. C. 202.

${ }^{11}$ Карасик В.И. О категориях лингвокультурологии. Языковая личность: проблемы коммуникативной деятельности: [сборник научных трудов]. Волгоград. 2001. C. 4. 
Лінгвокультурологія є однією із провідних і нових наукових галузей синтезуючого типу, що як галузь загальногуманітарного та лінгвістичного знання сформувалась в умовах парадигмальних змін у науці, пов'язаних, з одного боку, зі змінами у свідомості суспільства, 3 іншого - 3 упровадженням принципу антропоцентризму. У світовому мовознавстві термін лінгвокультурологія і досі залишається чітко невизначеним, зокрема $€$. Бартмінський ставить поняття етнолінгвістика, антропологічна лінгвістика, культурологічна лінгвістика та лінгвокультурологія в один ряд, порівн.: «Етнолінгвістика або лінгвістика антропологічна - опрацьована також під ширшими за обсягом назвами - культурологічна лінгвістика й лінгвокультурологія розвиваються у слов'янських краях у контакті з етнолінгвістикою західноєвропейською» ${ }^{12}$. А у пострадянській лінгвістичній традиції деякі науковці вважають лінгвокультурологію структурним складником сучасної когнітивної лінгвістики; інші дослідники (С. Воркачов, В. Телія) визнають лінгвокультурологію розділом етнолінгвістики: «Лінгвокультурологія - це сьогодні наймолодше відгалуження етнолінгвістики» ${ }^{13}$, або «лінгвокультурологія - це та частина етнолінгвістики, що присвячена вивченню та опису кореспонденції мови та культури у їх синхронній взаємодії» ${ }^{14}$. Втім, справедливим видається погляд В. Воробйова, який уважає, що «лінгвокультурологія пов'язана, а в деяких питаннях щільно змикається 3 етнолінгвістикою», але, на відміну від лінгвокультурології, «що орієнтується на сучасність і загальноприйняту нормативність, етнолінгвістика досліджує мову племен, діалектів, мовної родини та культурної групи, прамови та пракультури» 15 .

Формування нової наукової галузі гуманітарного знання лінгвокультурології - дослідники пояснюють необхідністю враховувати характеристики поведінки та спілкування різних народів у вирішенні різних питань, потребою знати заздалегідь ситуації, в яких $\epsilon$ ймовірність міжкультурного непорозуміння. Попри те, що в

${ }^{12}$ Bartmiński J. Etnolingwistyka słowiańska - prób bilansu. Etnolingwistyka. Lublin, 2004. Nr. 16. S. 135-136.

${ }^{13}$ Воркачев С.Г. Лингвокультурология, языковая личность, концепт: становление антропоцентрической парадигмы в языкознании. Филологические науки. 2001. № 1. C. 64.

${ }^{14}$ Телия В.Н. Русская фразеология: Семантический, прагматический и лингвокультурологический аспекты. Москва : Языки русской культуры, 1996. C. 217.

${ }^{15}$ Воробьёв В.В. О понятии лингвокультурологии и её компонентах. Язык $u$ культура: вторая международная конференция: Доклады / Укр. ин-т. междунар. отношений при Киевском ун-те им. Т.Г. Шевченка; [Сост. С. Б. Бураго]. Київ : Журнал «Collegium», 1993. C. 46-47. 
пострадянській лінгвістичній науці термін «лінгвокультурологія» 3'явився лише останнім часом у зв'язку із працями В. Воробйова, С. Воркачова, В. Карасика, В. Маслової, Ю. Степанова, В. Телія, чітке визначення цієї новоствореної галузі подає В. Воробйов: Лінгвокультурологія - це «комплексна наукова дисципліна про взаємозв'язок та взаємовплив культури і мови в ії функціонуванні, що відображає цей процес як цілісну структуру одиниць у єдності їх мовного та позамовного (культурного) змісту за допомогою системних методів й орієнтовно на сучасні пріоритети, що відображають нову систему цінностей» ${ }^{16}$. У межах цієї галузі можуть бути виокремлені концепції таких авторів, як Н. Арутюнова, І. Голубовська, В. Кононенко, М. Красавський, Т. Радзієвська, Г. Слишкін, О. Тищенко.

Звернення філологів до «культурологічної тематики» зумовлено, на думку В. Карасика, тим, що, «будучи багатомірним утворенням, мова органічно входить до найзагальніших феноменів буття: як найважливіший засіб спілкування мову розглядають як компонент комунікативної діяльності; як найважливіший засіб перетворення світу, інформаційного забезпечення та міжособистісного регулювання, мова аналізується як спосіб упливу, спонукання людей до тих чи тих дій, фіксації соціальних стосунків; як найважливіше вмістилище колективного досвіду мова $\epsilon$ складником культури» ${ }^{17}$. Відповідно до цього об'єктом досліджень у лінгвокультурології $\epsilon$ писемна культура як сукупність прецедентних текстів, а основні одиниці аналізу - «засоби мовної системи та ії дискурсивних продуктів, що фіксують культурно значущу інформацію збережені у колективній пам'яті народу символьні способи матеріального й духовного усвідомлення світу певним етносом, відтворені в його ідеях, схемах мислення й поведінки, системі етичних й естетичних цінностей, нормах, звичаях, обрядах, міфах, віруваннях, забобонах, побуті тощо» ${ }^{18}$. В. Маслова предметом лінгвокультурології вважає: 1) слова і вирази, що $\epsilon$ предметом лінгвокраїнознавства, тобто безеквівалентну лексику та лакуни; 2) міфологізовані культурно-мовні одиниці: архетипи, міфологеми, обряди, ритуали, звичаї, що закріплені в мові; 3) пареміологічний фонд мови; 4) фразеологічний фонд мови; 5) еталони, стереотипи, символи; 6) метафори та образи мови; 7) стилістичний уклад мови; 8) мовленнєву поведінку; 9) мовленнєвий етикет ${ }^{19}$.

${ }^{16}$ Там само. С. 47.

17 Карасик В.И. Языковой круг: личность, концепты, дискурс : монография. Волгоград : Перемена, 2002. С. 106.

${ }^{18}$ Селіванова О.О. Сучасна лінгвістика: термінологічна енциклопедія. Полтава. 2006. C. 303.

${ }^{19}$ Маслова В.А. Лингвокультурология: учебное пособие. Москва : Издательский центр «Академия», 2001. С. 36-37. 
Безперечно, лінгвокультурологія спирається на ідею про кумулятивну функцію мови, завдяки якій у мові зберігається та передається досвід народу. До завдань цієї наукової дисципліни В. Воробйов передусім відносить «цілісну системну репрезентацію мови та культури в їх взаємодії» ${ }^{20}$, тобто «вивчення та опис взаємозв'язків мови та культури, мови та етносу, мови та народного менталітету, оскільки ця наука створена, за прогнозом Е. Бенвеніста, «на основі тріади - мова, культура, людська особистість» 21.

Проаналізувавши основні засади лінгвокультурології та когнітивної лінгвістики, констатуємо, що об'єднувальним моментом у розвитку цих самостійних лінгвістичних галузей $\epsilon$ наявність концептуальних напрямів, одним із головних завдань яких є аналіз концептів.

Перші дослідники концептів працювали в річищі концептології, що виникла в межах культурології, зокрема Ю. Степанов зазначав, що концептологія, а точніше культурна концептологія - це «нова дисципліна, що вивчає так звані «культурні концепти», тобто поняття, що становлять культурну цінність» ${ }^{22}$. На думку В. Карасика та Й. Стерніна, концептологія - це не лише наука про концепти та їхній зміст, але і про відносини концептів у концептосфері, оскільки «концептологія досліджує як національні, так і групові, а також художні та індивідуальні концептосфери» ${ }^{23}$.

Будучи створеною в межах культурології, концептологія привернула увагу психологів, філософів та філологів, і поступово концептуально-культурологічний напрям починає посідати важливе місце в лінгвістичних дослідженнях та має міждисциплінарний характер. За свідченням В. Кононенка, «ідеї концептології як актуальної галузі знань, що грунтуються на спільних теоретикометодологічних засадах i принципах $\mathrm{i}$ проектуються на різні гуманітарні сфери, реалізуються в царині зіткнення наукових підходів $\mathrm{i}$ методик дослідження, зокрема 3 позицій психолінгвістики, лінгвокультурології, лінгвістичної філософії, пропозиційної логіки

${ }^{20}$ Воробьёв В.В. К понятию поля в лингвокультурологии (общие принципы). Русский язык за рубежом. 1991. № 5. С. 102.

${ }^{21}$ Воркачев С.Г. Лингвокультурология, языковая личность, концепт: становление антропоцентрической парадигмы в языкознании. Филологические науки. 2001. № 1. C. 64-65.

${ }^{22}$ Степанов Ю.С. «Интертекст», «Интернет», «Интерсубъект» (к основаниям сравнительной концептологии). Известия РАН. Серия литературы и языка. 2001. Т. 60 , № 1. С. 3 .

${ }_{23}$ Карасик В.И., Стернин И. А. Предисловие. Антология концептов: В 5 т. Москва : Генеза, 2007. Т. 1-2. 2007. С. 5. 
тощо» ${ }^{24}$. На думку С. Воркачова, саме «на стику лінгвокультурології та когнітивної лінгвістики можна прогнозувати становлення лінгвістичної концептології (лінгвоконцептології)» ${ }^{25}$, - науки, «що має за мету описати всі концепти, що існують у мові, лінгвістичними засобами» ${ }^{26}$.

Погоджуючись iз 3. Поповою та Й. Стерніним, головними завданнями лінгвістичної концептології визнаємо такі, як виявлення максимально повного складу мовних засобів, які репрезентують концепт, що досліджується; опис семантики цих одиниць (слів, словосполучень, асоціативних полів, паремій, текстів); моделювання змісту концепту як глобальної ментальної одиниці в іiї національній (можливо в соціальній, віковій, гендерній, територіальній) своєрідності та визначення місця цього концепту в концептосфері ${ }^{27}$.

Визнаючи лінгвістичну концептологію окремою науковою галуззю, науковці не мають єдиної точки зору стосовно походження цієї науки та іiі зв'язку з іншими лінгвістичними дисциплінами, зокрема В. Іващенко вважає, що лінгвістична концептологія виникла в контексті функціоналізму та генеративізму, на межі взаємодії когнітивної та антропоцентричної наукових парадигм; О. Селіванова зазначає, що лінгвоконцептологія як нова галузь виокремилась у складі когнітивної лінгвістики; 3. Попова та Й. Стернін уважають лінгвоконцептологію одним із напрямів лінгвокогнітології; а на думку С. Воркачова, «лінгвокультурна концептологія виділилась із лінгвокультурології в процесі переакцентуації і модифікації компонентів у складі тріади «мова, культура, особистість», що ii намітив Е. Бенвеніст ${ }^{28}$. Оскільки О. Селіванова вказує на існування концептуального напряму як у межах лінгвокультурології, так і в когнітивній лінгвістиці, то це дає змогу констатувати: первісно метою концептології, що виникла на основі культурології, був усебічний аналіз культурних концептів, але концепт - це поняття ментальне, а культура щільно пов'язана 3 мовою, тому аналіз концептів поступово стає прерогативою інтегральних дисциплін лінгвістичного спрямування - когнітивної лінгвістики, лінгвокультурології, психолінгвістики, етнолінгвістики, і у межах цих

${ }^{24}$ Кононенко В.І. Концептологія в лінгвістичному аспекті. Мовознавство. 2006. № 2-3. C.111.

${ }^{25}$ Іващенко В.Л. Концептуальна репрезентація фрагментів знання в науковомистецькій картині світу (на матеріалі української мистецтвознавчої термінології): Монографія. Київ : Видавничий Дім Дмитра Бураго, 2006. С. 3.

26 Карасик В.И., Стернин И.А. Предисловие. Антология концептов: В 5 т. Москва : Генеза, 2007. Т. 1. 2007. С. 5.

27 Попова З.Д., Стернин И.А. Когнитивная лингвистика. Москва : АСТ. 2007. C. $22-23$.

${ }^{28}$ Воркачев С.Г. Постулаты лингвоконцептологии. Антология конщептов: В 5 т. Москва : Генеза, 2007. Т. 1. 2007. С. 10. 
дисциплін розвивається новий напрям - концептологічний. Але, як зазначають В. Карасик та Й. Стернін, «судячи з кількості публікацій у лінгвістичних збірках наукових праць, моделювання концептів стало одним із напрямів сучасної філології, що розвивається найактивніше» $^{29}$, тому виникла потреба у створенні окремої лінгвістичної галузі, головною метою якої був би аналіз концептів та засобів їх мовної репрезентації. Цією галуззю і стала лінгвістична концептологія.

\section{2. Поняття «концепт» у сучасній лінгвістиці}

Феномен «концепт» набув широкого розповсюдження та став «модним і навіть «ласим» об'єктом вивчення» в сучасних розвідках, але він поки що не має однозначного визначення. В. Карасик зазначає, що «лінгвісти намагаються позбутися багатозначності терміну «концепт» ${ }^{30}$ і пропонують альтернативні аналоги: «лінгвокультурема» (В. Воробйов), «міфологема» (В. Базилєв), «логоепістема» (Е. Верещагін, В. Костомаров), «концептуал» (О. Бунєєва), що їх починають уживати у лінгвістичній літературі 3 початку 90-х років ХХ ст.

Термін «концепт» було запозичено західними лінгвістами завдяки працям Г. Фреге та А. Черча 3 математичної логіки. На теренах колишнього СРСР цей термін першим увів С. Аскольдов, який уважав, що «питання про природу загальних понять або концептів - у середньовічній термінології універсалій - старе питання, проте майже не розглянуте у центральному пункті» ${ }^{31}$. Отже, термін «концепт»у лінгвістиці - старий та новий одночасно, що уводиться 3 відомою долею пафосу та через когнітивну метафору: це i «брунька найскладніших суцвіть», i «ембріон уявних операцій», i «квант знання», i «згусток культури», i «ген культури».

Оскільки термін «концепт» 3'являється у лінгвістичній семантиці завдяки взаємодії лінгвістики з філософією, психологією, культурною антропологією, то, відповідно, концепт розглядається у різних векторах, у межах яких виділяють численні дефініції, тому можна виділити кілька підходів до інтерпретації концепту, що докладно розглянуті у працях В. Іващенко, В. Карасика, А. Костіна,

29 Карасик В.И., Стернин И.А. Предисловие. Антология концептов: В 5 т. Москва : Генеза, 2007. Т. 1-2. 2007. С. 5.

30 Карасик В.И. О категориях лингвокультурологии. Языковая личность: проблемы коммуникативной деятельности: [сборник научных трудов]. Волгоград. 2001. C. 14.

зі Аскольдов С.А. Концепт и слово. Русская словесность. От теории словесности к структуре текста: антология / [под общ. ред. В. П. Нерознака]. Москва : Academia, 1997. С. 267. 
Ж. Краснобаєвої-Чорної, О. Мальцевої, В. Маслової, Т. Монахової, I. Палашевської, О. Прохвачової, Н. Слухай, Тянь Цзюнь.

I. Як слушно зазначає Н. Слухай, «визначення концепту в рамках філософської теорії пізнання та відображення дійсності варіюються у такому діапазоні: від широкого (складні ментальні утворення - думка, знання, віра, причина, - осмислені на основі широкого онтологічного фону речей, які складають оточуючий світ, та власного досвіду людини) до дещо звуженого (смисли, якими оперує людина у процесі згортання, або інтеріоризації, знання про оточуючий світ, які зберігаються у вигляді квантів - таких, як життя, смерть)» ${ }^{32}$. У межах філософської парадигми можна виділити такі підходи до розуміння концептів: власне філософський та логіко-філософський.

1. Філософський підхід пов'язують переважно 3 ідеями концептуалізму як одного 3 напрямів середньовічної схоластичної філософії, започаткованого, на думку дослідників, Д. Скоттом або П. Абеляром. Концептуалісти твердили, що в одиничних речах є дещо спільне, загальне, на основі чого в розумі виникає концепт - особливе загальне поняття, виражене словом.

2. Набувши статусу наукового поняття, термін «концепт» починає вживатися у логіці, що спричиняє виникнення логіко-філософського niдxoдy до інтерпретації концепту, який спирається на ідеї аналітичної школи філософії, що складається 3 двох напрямів: лінгвістична філософія та логічний аналіз мови. Представники цих напрямів (Д. Остін, Р. Карнап, Г. Райл, Б. Рассел, Г. Фреге, А. Черч) висловили думку про те, що саме мову треба вважати головним об'єктом філософії як науки, та почали розглядати концепти як «логічні категорії, а не як ментальні сутності» ${ }^{33}$.

II. Той факт, що більшість мовних понять не мають чітко окреслених меж, стимулює пошуки у різних галузях та дає змогу спостерігати появу логічної парадигми в розумінні концепту. Підгрунтя логічної парадигми було закладено представниками лінгвістичної філософії та логічного аналізу мови, тому можна виокремити такі підходи: лінгво-логіко-філософський, логіко-поняттєвий, логікосемантичний.

1. Лінгво-логіко-філософський підхід до розуміння концепту подано у роботі Р. Павільоніса «Проблема смислу: сучасний логіко-

32 Слухай Н.В. Сучасні лінгвістичні теорії концепту як мовно-культурного феномену. Мовні і концептуальні картини світу: [збірник наукових праць]. Київ : КНУ ім. Т.Г. Шевченка, 2002. С. 464.

${ }_{33}$ Іващенко В.Л. Концептуальна репрезентація фрагментів знання в науковомистецькій картині світу (на матеріалі української мистецтвознавчої термінології): Монографія. Київ : Видавничий Дім Дмитра Бураго, 2006. С. 12. 
філософський аналіз мови». Описуючи концептуальну систему (у значенні концептуальна картина світу), Р. Павільоніс зазначає, що «інформація, яка міститься у концептуальній системі, служить як для сприйняття означених об'єктів, так і для виділення мови як особливого об’єкта: їх співвідношення, що реалізується концептуальною системою, $\epsilon$ кодування мовними засобами окремих фрагментів, «шматків» концептуальної системи». Під фрагментом концептуальної системи він розуміє концепт, визначаючи його як «інформацію відносно актуального або можливого стану речей у світі, те, що ми називаємо «смислом» ${ }^{34}$.

2. Значний внесок у розвиток теорії концепту зробила представниця польської лінгвістичної школи А. Вежбицька, яка застосовує логіко-поняттєвий підхід до вивчення концептів і трактує концепт як «об'єкт зі світу «Ідеальне», що має ім'я та відображає певні культурно зумовлені уявлення людини про світ «Дійсність» ${ }^{35}$. Сама ж дійсність, на думку А. Вежбицької, дана нам у мисленні саме через мову. За цією теорією, концепти - це уявні утворення, що пояснюють, як побудоване довкілля. Отже, А. Вежбицька пропонує вивчення концептів як інструментів пізнання зовнішньої дійсності, що описані засобами мови у вигляді деяких пояснювальних конструкцій.

3. Логічний аналіз мови орієнтується на моделювання структур репрезентації знань і на концептуальний аналіз (проект «Логический анализ языка» РАН під керівництвом Н. Арутюнової). Н. Арутюнова та представники її школи (Т. Булигіна, С. Нікітіна, О. Шмельов та інші) застосовують логіко-семантичний підхід до інтерпретації концепту, який дає змогу розглядати концепти як поняття практичної філософії, що виникають «унаслідок взаємодії таких фактів, як національна традиція і фольклор, релігія та ідеологія, життєвий досвід та образи мистецтва, відчуття та система цінностей» ${ }^{36}$. Назва підходу пояснюється тим, що концепти вивчаються як семантичні домінанти, що мають поняттєво-структурне значення та описуються за допомогою методу логічного аналізу мови, що його розробляє Московська семантична школа.

III. Розвиток лінгвістики поступово переорієнтується, і якщо раніше вона співвідносилась із логікою та спиралась на іiі поняття, то на

${ }^{34}$ Павилёнис Р.И. Проблемы смысла: современный логико-философский анализ языка. Москва : Мысль, 1983. С. 102.

35 Фрумкина Р.М. «Теории среднего уровня» в современной лингвистике. Вопросы языкознания. 1996. № 2. С. 59.

${ }^{36}$ Арутюнова Н.Д. Введение. Логический анализ языка: Ментальные действия / Рос. АН, Ин-т языкознания; [отв. ред. Н.Д. Арутюнова, Н.К. Рябцева]. Москва : Наука, 1993. С. 3. 
новому етапі розвитку лінгвісти звертаються до психології, формуючи психологічну парадигму у розумінні концепту. Психологічна парадигма репрезентована психологічним, когнітивним та семантикокогнітивним підходами.

1. Звернувшись одним із перших у світовій лінгвістиці до вивчення концептів, С. Аскольдов запропонував таку дефініцію: «Концепт $€$ мисленнєве утворення, що заступає нам у процесі думки невизначену множинність предметів одного й того ж роду... Не слід, звичайно, вважати, що концепт є завжди замісником реальних предметів. Він може бути замісником деяких ознак предмета чи реальних дій, як, наприклад, концепт «справедливість» ${ }^{37}$. Продовжуючи міркування С. Аскольдова, Д. Лихачов пояснює концепт як «алгебраїчний» вираз значення, що ним оперують у письмовому та усному мовленні. Справді, те чи інше слово не викликає у нашій свідомості набір ознак, що формують його словникове значення або логічне поняття, «бо охопити значення в усій його складності людина просто не встигає, іноді не може, а іноді інтерпретує його по-своєму (залежно від своєї освіти, власного досвіду, професії тощо)» ${ }^{38}$. Погоджуючись із думками О. Бабаєвої, В. Карасика, О. Клименко, О. Прохвачової, вважаємо, що згадані науковці використовують психологічний пiдxid до інтерпретації концепту.

2. Когнітивний niдxid, що виник на межі кількох наукових дисциплін, має велику кількість прихильників (М. Болдирев, В. Дем'янков, С. Жаботинська, В. Іващенко, О. Кубрякова, О. Рахіліна, Н. Рябцева, О. Селіванова). У межах цього підходу концепт - це одиниця пізнання, ментального лексикону. Класичне тлумачення такого концепту розробила О. Кубрякова: «Концепт - термін, що служить поясненню одиниць ментальних і психічних ресурсів нашої свідомості й тієї інформаційної структури, що відображає знання й досвід людини; оперативна змістовна одиниця пам'яті, ментального лексикону, концептуальної системи й мови мозку, всієї картини світу, відображеної у психіці людини» ${ }^{39}$. У вітчизняному мовознавстві таке розуміння концепту стало підгрунтям для дефініції, запропонованої

37 Аскольдов С.А. Концепт и слово. Русская словесность. От теории словесности к структуре текста: антология / [под общ. ред. В.П. Нерознака]. Москва : Academia, 1997. C. 267-270.

38 Лихачев Д.С. Концептосфера русского языка. Русская словесность. От теории словесности к структуре текста / [под общ. ред. В.П. Нерознака]. Москва : 1997. C. 281.

39 Кубрякова Е.С. Краткий словарь когнитивных терминов [Текст] / Е.С. Кубрякова, В.З. Демьянков, Ю.Г. Панкрац, Л.Г. Лузина; / [под общ. ред. Е.С. Кубряковой]. Москва : Филологический факультет МГУ им. М.В. Ломоносова, 1996. C. 90. 
О. Селівановою: «Концепт - інформаційна структура свідомості, різносубстратна, певним чином організована одиниця пам'яті, яка містить сукупність знань про об'єкт пізнання, вербальних i невербальних, набутих шляхом взаємодії п'яти психічних функцій свідомості й позасвідомого» ${ }^{40}$.

3. Спираючись на теорію смислу та теорію референції, О. Бабушкін розглядає концепт у межах когнітивної семантики - застосовує семантико-когнітивний підхід, згідно з яким концепти відповідають змісту семем кожної окремої мови. О. Бабушкін визначає концепт як «деяку дискретну одиницю колективної свідомості, що відображає предмет реального або ідеального світу, який зберігається у національній пам'яті носіїв мови у вигляді пізнаного субстрату» ${ }^{41}$, а ідеальна сутність концепту матеріально втілюється у словах мови, оскільки у самому слові фіксуються результати когнітивних зусиль людського розуму. 3. Попова та Й. Стернін також визначають власний підхід до дослідження концепту як семантико-когнітивний, головним постулатом якого $є$ розуміння концепту як «глобальної мисленнєвої одиниці, що $\epsilon$ квантом структурованого знання» ${ }^{42}$. Представниця Кемеровської лінгвістичної школи М. Піменова зазначає, що «когнітивний підхід у дослідженні семантики полягає у вивченні самого значення слова, в якому фіксуються не лише ознаки, необхідні та достатні для ідентифікації того, що позначається, але й наївні знання про те, що позначається» ${ }^{43}$. М. Піменова також зауважує, що концепт це основна одиниця ментальності, яка має мовну форму вербалізації, національну специфіку і структуру, що містить концептуальні ознаки, важливі для відповідної культури. Семантичну інтерпретацію концепт набуває й у дослідженнях М. Алефіренка: «Концепт - це мисленнєве утворення, що заміщує у свідомості невизначену множинність однорідних предметів та $€$ когнітивною основою для формування різних лексичних значень слова» ${ }^{44}$.

4. Сучасне вивчення мови в аспекті іiі взаємодії з культурою призводить до виникнення культурологічної парадигми, націленої на розуміння концепту як явища культури. Сьогодні ця парадигма

${ }^{40}$ Селіванова О.О. Сучасна лінгвістика: термінологічна енциклопедія. Полтава : Довкілля-К, 2006. С. 256.

41 Бабушкин А.П. Типы концептов в лексико-фразеологической семантике языка. Воронеж : Изд-во Воронежского государственного университета, 1996. С. 29.

${ }^{42}$ Попова 3.Д., Стернин И.А. Очерки по когнитивной лингвистике. Воронеж, 2001. C. 4.

43 Пименова М.В. Методология концептуальных исследований. Антология кониептов: В 5 т.Москва : Генеза, 2007. Т. 1. 2007. С. 14.

44 Алефиренко Н.Ф. Фразеологическое значение и концепты. Когнитивная семантика: В 2 ч. Тамбов : Изд-во ТГУ, 2000. Ч. 2. С. 34. 

етнолінгвістичним та інтегративним підходами.

1. Безпосередньо культурологічне сприйняття концепту подають Ю. Степанов та В. Нерознак, для яких концепт є поняттям духовної культури. Культурологічний підхід, на їх думку, спрямований на соціальну сутність концептів, а не на індивідуально-психологічні особливості. Ю. Степанов розглядає концепт як «основний осередок культури в ментальному світі людини» ${ }^{45}$, а В. Нерознак пропонує критерій для віднесення певних концептів до культурних: «Концептами культури, що відображають національну картину світу, треба вважати концепти, що позначаються безеквівалентною лексикою» ${ }^{46}$, тобто ті концепти, які властиві носіям конкретної культури.

2. Лінгвокультурологічний підхід формується на основі необхідності синтезу культурних та світоглядних категорій у семантиці імен. Серед лінгвокультурологів найбільш популярним визначенням концепту $\epsilon$ таке, що його пропонує засновник Московської школи лінгвокультурологічного аналізу фразеологізмів В. Телія, порівн.: «Концепт - це знання про означуване в усіх його зв'язках та відносинах» ${ }^{47}$. Свою дефініцію подає і С. Воркачов: «Концепт - це культурно позначений вербалізований смисл, що репрезентований у плані вираження цілою низкою мовних реалізацій, що утворюють відповідну лексико-семантичну парадигму» ${ }^{48}$. Вітчизняні мовознавці, зокрема Л. Даниленко, В. Кононенко, Т. Радзієвська, Н. Слухай, не подаючи власного визначення концепту, також позиціонують лінгвокультурологічний підхід.

3. Попри те, що етнолінгвістика як наука сформувалась у межах американської та російської лінгвістичних традицій, найбільшу популярність етнолінгвістичний підхід (у зв'язку із концептом) отримує в працях українських науковців. Етнолінгвістичний niдxід використовує передусім у своїх роботах В. Жайворонок, який пише: «Пізнаючи і членуючи навколишній світ, людина не лише називає (іменує) окремі його реалії, а й осмислює їх у слові, тому постає

45 Степанов Ю.С. Константы: Словарь русской культуры. Опыт исследования. Москва : Школа «Языки русской культуры», 1997. С. 41

46 Нерознак В.П. От концепта к слову: к проблеме филологического концептуализма. Вопросы филологии и методики преподавания иностранных языков: [сб. науч. тр.]. Омск : Изд-во ОМГПУ, 1998. С. 85.

${ }^{47}$ Телия В.Н. Русская фразеология: Семантический, прагматический и лингвокультурологический аспекты. Москва : Языки русской культуры, 1996. C. 100 .

${ }^{48}$ Воркачев С.Г. «Две доли» - две концепции счастья. Языковая личность: проблемы креативной семантики: [сборник научных трудов]. Волгоград : Перемена, 2000. C. 56. 
потреба говорити не просто про слова, а про мовні одиниці - культурні (етнокультурні) концепти» ${ }^{49}$. Незважаючи на відсутність власної дефініції концепту, властиву йому етноспецифічність не заперечує й O. Тищенко, а I. Голубовська вважає, що концепти - це унікальні поняття етнічної культури.

4. Осмислення природи концептів можливе тільки за комплексного підходу до цього явища. У працях сучасних науковців такий підхід отримав різні назви: універсальний (О. Мальцева, О. Прохвачова), комплексний (O. Клименко, O. Прохвачова), диференційний (О. Тряпицина), інтегративний / інтегральний (В. Карасик, Ж. Краснобаєва-Чорна, I. Палашевська). Безперечно, дослідити концепти можна лише інтегруючи знання і методи багатьох наук, тому називаємо такий підхід інтегративним. Інтегративний підхід до концепту був запропонований С. Ляпіним, який уважав, що головне в концепті - це «багатомірність та дискретна цілісність смислу, що існує у безперервному культурно-історичному просторі і тому схильний до культурної трансляції 3 однієї предметної галузі в іншу» ${ }^{50}$. Представники Волгоградської лінгвістичної школи теж дотримуються цього підходу, зокрема Г. Слишкін уважає концепт «одиницею, що пов'язує наукові дослідження у галузі культури, свідомості та мови, оскільки він належить свідомості, детермінується культурою та опредмечується у мові» ${ }^{51}$. Отже, інтегративний підхід передбачає взаємозв'язок лінгвістичного, психологічного, культурологічного та інших аспектів.

\section{ВИСНОВКИ}

Установлення нової антропоцентричної парадигми привертає увагу лінгвістів до взаємодії мови із мисленням, свідомістю, культурою. Це сприяє формуванню нових лінгвістичних галузей, зокрема когнітивної лінгвістики та лінгвокультурології. Об'єднувальним моментом у розвитку цих двох самостійних лінгвістичних галузей є наявність концептуальних напрямів, одним із головних завдань яких $\epsilon$ аналіз концептів. У зв'язку із цим завданням на базі когнітивної лінгвістики та лінгвокультурології виникає нова лінгвістична дисципліна, що вивчає концепти, лінгвістична концептологія. У межах лінгвоконцепології виділяють два основні підходи: лінгвокультурологічний та лінгвокогнітивний,

49 Жайворонок В.В. Етнолінгвістика в колі суміжних наук. Мовознавство. 2004. № 5-6. С. 26.

50 Ляпин С.Х. Концептология: к становлению подхода. Концепты. Hayчные труды Центроконцепта. Архангельск, 1997. Вып. 1. С. 19.

51 Слышкин Г.Г. От текста к символу: лингвокультурные концепты прецедентных текстов в сознании и дискурсе. Москва : Academia, 2000. С. 9. 
різниця між якими полягає в розумінні поняття концепту та методики його аналізу.

Поняття концепт належить до фундаментальних понять сучасної лінгвістики. Підсумовуючи огляд підходів до розуміння концепту, наголосимо, що кожен із названих підходів не вичерпує поняття «концепт», але дає змогу глибше пізнати його природу. Слід визнати, що розглянуті теорії часто виступають як перехресні, співвіднесені та $\epsilon$ комплексними. Концепт трактуємо як багатомірне культурно значуще соціопсихічне утворення, що може мати мовне вираження.

Безліч концептів, що їх покористовують лінгвісти, породила різні класифікації концептів, репрезентовані в науковій літературі, але жодну із цих класифікацій не можна вважати загальноприйнятою. Нерозв'язаним залишається і питання методів та методик аналізу концепту, що й становить перспективу для подальших досліджень у сучасний період розвитку науки.

\section{АНОТАЦІЯ}

Статтю присвячено висвітленню теоретичних засад лінгвоконцептології, зокрема йдеться про взаємодію мови із мисленням та культурою, що сприяє формуванню нових лінгвістичних галузей, передусім когнітивної лінгвістики та лінгвокультурології. Зазначається, що об'єднувальним моментом у розвитку цих двох лінгвістичних дисциплін $\epsilon$ наявність концептуальних напрямів, одним із головних завдань яких $\epsilon$ аналіз концептів. У зв'язку із цим завданням на базі когнітивної лінгвістики та лінгвокультурології виникає лінгвістична дисципліна, що вивчає концепти, лінгвістична концептологія. У межах лінгвоконцепології виділяють два основні підходи: лінгвокультурологічний (Н. Арутюнова, C. Воркачов, I. Голубовська, В. Карасик, Г. Слишкін,) та лінгвокогнітивний (О. Бабушкін, С. Жаботинська, В. Іващенко, О. Кубрякова, М. Піменова, 3. Попова, Й. Стернін, О. Селіванова), різниця між якими полягає у розумінні поняття концепту та методики його аналізу. Базовою одиницею лінгвоконцептології $€$ концепт, що його розглядають у вигляді п'яти парадигм: 1) філософська, у межах якої існує філософський та логікофілософський підходи до розуміння концепту; 2) логічна, що базується на лінгво-логіко-філософському, логіко-поняттєвому та логіко-семантичному підходах; 3) психологічна, що репрезентована психологічним, когнітивним та семантико-когнітивним підходами; 4) культурологічна, що в її межах виокремлюємо культурологічний, лінгвокультурологічний, етнолінгвістичний, інтегративний підходи. 


\section{ЛIТЕРАТУРА}

1. Алефиренко Н.Ф. Фразеологическое значение и концепты. Когнитивная семантика: В 2 ч. Тамбов : Изд-во ТГУ, 2000. Ч. 2. C. 33-36.

2. Арутюнова Н.Д. Введение. Логический анализ языка: Ментальные действия / отв. ред. Н.Д. Арутюнова, Н.К. Рябцева. Москва : Наука, 1993. С. 3-6.

3. Аскольдов С.А. Концепт и слово. Русская словесность. От теории словесности к структуре текста: антология / под общ. ред. В.П. Нерознака. Москва : Academia, 1997. С. 267-279.

4. Бабушкин А.П. Типы концептов в лексико-фразеологической семантике языка. Воронеж, 1996. 104 с.

5. Bartmiński J. Etnolingwistyka słowiańska - prób bilansu. Etnolingwistyka. Lublin, 2004. Nr. 16. S. 135-143.

6. Воркачев С.Г. «Две доли» - две концепции счастья. Языковая личность: проблемы креативной семантики. Волгоград. 2000. С. 52-61.

7. Воркачев С.Г. Лингвокультурология, языковая личность, концепт: становление антропоцентрической парадигмы в языкознании. Филологические науки. 2001. № 1. С. 64-72.

8. Воркачев С.Г. Постулаты лингвоконцептологии. Антология концептов: В 5 т. Москва : Генеза, 2007. Т. 1. 2007. С. 10-11.

9. Воробьёв В.В. К понятию поля в лингвокультурологии (общие принципы). Русский язык за рубежом. 1991. № 5. С. 101-106.

10. Воробьёв В.В. О понятии лингвокультурологии и её компонентах. Язык и культура : Доклады / [Сост. С. Б. Бураго]. Київ. 1993. С. $42-48$.

11. Голубовська І.О. Етнічні особливості мовних картин світу : монографія. Київ 2004. 284 с.

12. Жайворонок В.В. Етнолінгвістика в колі суміжних наук. Мовознавство. 2004. № 5-6. С. 23-35.

13. Загнітко А.П. Сучасні лінгвістичні теорії : монографія. Донецьк. 2006. $338 \mathrm{c}$.

14. Іващенко В.Л. Концептуальна репрезентація фрагментів знання в науково-мистецькій картині світу (на матеріалі української мистецтвознавчої термінології) : монографія. Київ : Видавничий Дім Дмитра Бураго, 2006. 328 с.

15. Карасик В.И. О категориях лингвокультурологии. Языковая личность: проблемы коммуникативной деятельности. Волгоград. 2001. C. $3-16$.

16. Карасик В.И., Слышкин Г.Г. Базовые характеристики лингвокультурных концептов Антология концептов: В 5 т. Москва, 2007. T. 1. 2007. C. $12-13$. 
17. Карасик В.И., Стернин И.А. Предисловие. Антология кониептов: В 5 т. Москва : Генеза, 2007. Т. 1-2. 2007. С. 5-6.

18. Карасик В.И. Языковой круг: личность, концепты, дискурс : монография. Волгоград : Перемена, 2002. 477 с.

19. Кононенко В.I. Концептологія в лінгвістичному аспекті. Мовознавство. 2006. № 2-3. С. 111-117.

20. Кубрякова Е.С. Краткий словарь когнитивных терминов / Е.С. Кубрякова, В.З. Демьянков, Ю.Г. Панкрац, Л.Г. Лузина; / под общ. ред. Е.С. Кубряковой. Москва, 1996. 248 с.

21. Лихачев Д.С. Концептосфера русского языка. Русская словесность. От теории словесности к структуре текста / под общ. ред. В.П. Нерознака. Москва : 1997. С. 280-287.

22. Ляпин С.Х. Концептология: к становлению подхода. Кониепты. Научные труды Центроконщепта. Архангельск, 1997. Вып. 1. С. 11-35.

23. Маслова В.А. Введение в когнитивную лингвистику : учебное пособие. Москва : Флинта : Наука, 2004. 296 с.

24. Маслова В.А. Лингвокультурология : учебное пособие. Москва, 2001. $208 \mathrm{c}$.

25.Нерознак В.П. От концепта к слову: к проблеме филологического концептуализма. Bопросы филологии $u$ методики преподавания иностранных языков: [сб. науч. тр.]. Омск : Изд-во ОМГПУ, 1998. С. 80-85.

26. Павилёнис Р.И. Проблемы смысла: современный логикофилософский анализ языка. Москва : Мысль, 1983. 286 с.

27. Пименова М.В. Методология концептуальных исследований. Антология концептов: В 5 т. Москва : Генеза, 2007. Т. 1. 2007. C. $14-16$.

28. Попова 3.Д., Стернин И.А. Когнитивная лингвистика. Москва, 2007. 314, [6] c.

29. Попова З.Д., Стернин И.А. Основные черты семантикокогнитивного подхода к языку Антология концептов: В 5 т. Москва, 2007. Т. 1. 2007. С. 7-9.

30. Попова 3.Д., Стернин И.А. Очерки по когнитивной лингвистике. Воронеж. 2001. $191 \mathrm{c}$.

31. Селіванова О.О. Актуальні напрями сучасної лінгвістики (аналітичний огляд). Київ, 1999. 148 с.

32. Селіванова О.О. Сучасна лінгвістика: термінологічна енциклопедія. Полтава : Довкілля-К, 2006. 716 с.

33. Слухай Н.В. Сучасні лінгвістичні теорії концепту як мовнокультурного феномену. Мовні $і$ концептуальні картини світу. Київ, 2002. C. 462-470. 
34. Слышкин Г.Г. От текста к символу: лингвокультурные концепты прецедентных текстов в сознании и дискурсе. Москва : Academia, 2000. $128 \mathrm{c}$.

35. Степанов Ю.С. «Интертекст», «Интернет», «Интерсубъект» (к основаниям сравнительной концептологии). Известия РАН. Серия литературы и языка. 2001. Т. 60, № 1. С. 3-11.

36. Степанов Ю.С. Константы: Словарь русской культуры. Опыт исследования. Москва : Школа «Языки русской культуры», 1997. 824 с.

37. Телия В.Н. Русская фразеология: Семантический, прагматический и лингвокультурологический аспекты. Москва, 1996. $288 \mathrm{c}$.

38. Фрумкина Р.М. «Теории среднего уровня» в современной лингвистике. Вопросы языкознания. 1996. № 2. С. 55-67.

Information about the author:

Plotnikova N. V.,

Candidate of Philological Sciences, Associate Professor at the Foreign Languages Department National University of Pharmacy 53, Puchkinskaya str., Kharkiv, 61002, Ukraine 